\title{
Tito Flavio Vespasiano y Júpiter Óptimo Máximo: la justificación propagandístico- religiosa de una nueva dinastía imperial en Roma
}

\author{
Titus Flavius Vespasian and luppiter Optimus Maximus: \\ propagandistic religious legitimation \\ of a new imperial dynasty in Rome
}

\author{
Diego M. Escámez De Vera*
}

\begin{abstract}
RESUMEN
El ascenso a la dignidad imperial por parte de la dinastía Flavia se vio marcado profundamente por una grave crisis psicológica de la población, derivada de los diversos desastres acaecidos a lo largo de las guerras civiles enmarcadas en el denominado "Año de los cuatro emperadores" y la destrucción del templo de Júpiter. Las fuentes clásicas, la epigrafía y la iconografía numismática se convierten en este contexto en un medio de propaganda y justificación religiosa del poder político de Vespasiano y sus hijos. Vespasiano, como reconstructor del Capitolio, será identificado como el
\end{abstract}

\begin{abstract}
The promotion to the imperial dignity by the Flavian dynasty was deeply marked by a severe psychological crisis of the population, derived from the various disasters that occurred during the civil wars framed in the "Year of the Four Emperors" and the destruction of the temple of luppiter. Classical sources, epigraphy and numismatic iconography were converted in this context in the propaganda media and religious legitimization of the political power of Vespasian and his sons. Vespasian, as rebuilder of the Capitol, will be identified as the restorer of the city itself, as the
\end{abstract}

" Universidad Complutense de Madrid, C/Profesor Aranguren s/n, Ciudad Universitaria 28040 Madrid: iacobus6@ hotmail.com

Para el siguiente artículo se han utilizado las siguientes traducciones de fuentes clásicas: CICERÓN, Sobre la adivinación ; Sobre el destino ; Timeo (Trad. de Ángel Escobar) Madrid. Gredos. 1999

DIÓN CASIO, Dio's Roman history; (trad. Earnest Cary), Cambridge. Harvard University Press. 1970. FLAVIO JOSEFO, Antigüedades judías; (trad. José Vara Donado), Torrejón de Ardoz. Akal. 1997. - La guerra de los judíos.; (trad. de Jesús María Nieto lbáñez), Madrid. Gredos. 1999.

SUETONIO, Vida de los Doce Césares; (trad. Mariano Bassols de Climent), Madrid. CSIC. 1999. TÁCITO, Historias; (trad. José Luis Moralejo), Madrid, Akal. 1990. 
restaurador de la propia urbe, como el garante último de la voluntad de los dioses. En el siguiente trabajo trataremos, por tanto, de identificar las claves del sistema propagandístico flavio a partir de las fuentes del periodo e indagar en el modelo religioso creado expresamente para la identificación del emperador con el mantenimiento de la integridad del imperio bajo la égida de la principal divinidad del panteón romano: Júpiter Óptimo Máximo.

PALABRAS CLAVE:

Júpiter Óptimo Máximo, dinastía Flavia, propaganda, legitimación religiosa. ultimate guarantor of the will of the gods. In this article we will try to identify the keys of the flavian propaganda system from the sources of the period and to investigate the religious model created specifically for the identifying the emperor with the maintaining of the integrity of the empire under the aegis of the main divinity of the Roman pantheon: luppiter Optimus Maximus.

\section{KEYWORDS:}

luppiter Optimus Maximus, Flavian dynasty, propaganda, religious legitimization.

Recibido el 2 de junio de 2012. Aceptado el 11 de septiembre de 2012

\section{INTRODUCCIÓN}

El reinado de Vespasiano es, sin ninguna duda, uno de los principales periodos de desarrollo de la propaganda imperial en la historia de Roma. La desestabilización a la que se había visto abocado el Estado, tras un largo periodo de contiendas civiles y la rápida sucesión de cuatro usurpadores en el trono imperial, había llevado a una grave crisis de la mentalidad colectiva romana. De esta manera, los desastres de la guerra serán vistos por parte de la población, según lo que podemos deducir de las fuentes del periodo, como el castigo divino por la impiedad de la sociedad y de sus gobernantes.

Frente a tal clima de crisis psicológica del pueblo romano, y frente a la receptividad exaltada hacia los sucesos milagrosos con motivo de la misma, Vespasiano desarrollará un programa ideológico, político y propagandístico en pos de reforzar la legitimidad de su ascenso al poder. De este modo, frente a sus antecesores en el trono, Galba, Otón y Vitelio, Vespasiano se presentará como heredero legítimo de la legalidad imperial iniciada con Augusto y mantenida a lo largo de la dinastía Julio-Claudia hasta la muerte de Nerón.

Dicha justificación pasa por la sanción divina del poder alcanzado por las armas. Con esta intención, Vespasiano realizará un programa ideológico en torno a la figura de Júpiter, como deidad principal del panteón romano y representante celeste del poder. Esta elección vendrá derivada, por un lado, de la utilización tradicional de Júpiter por parte de los emperadores y, por otro, de la destrucción del Capitolio durante las luchas entre vitelianos y flavianos, utilizada por Vespasiano como baza propagandística.

De esta manera, la reconstrucción del Capitolio por parte de Vespasiano supondrá, para el pueblo romano, la superación del periodo de crisis y la vuelta a la 
normalidad, conseguida tan sólo a través del apoyo de los dioses hacia el nuevo emperador, quién se convertirá en un modelo intachable de pietas hacia la divinidad. Se presenta, por tanto, un retorno a la edad de oro augustea tras un largo periodo de malos gobiernos y emperadores ilegítimos, una revalorización de la figura imperial desprestigiada por los continuos golpes de Estado.

Nuestra intención, por tanto, es demostrar, a través de las fuentes clásicas y la numismática, la creación de un programa iconográfico y propagandístico coherente y capaz de imponer el mensaje ideológico mantenido desde el poder. La existencia de un mensaje unitario, característica fundamental de la propaganda, se verá cumplida en el caso flaviano, al presentar, mediante diferentes vías de penetración, un mismo mensaje: la justificación del poder de Vespasiano, y por extensión de sus hijos, a través de la consideración de la continuidad respecto a la legalidad JulioClaudia y el apoyo incondicional de la principal deidad del panteón romano, Júpiter Óptimo Máximo.

\section{LOS PRESAGIOS COMO FÓRMULA PROPAGANDÍSTICA IMPERIAL: EL CASO DE VESPASIANO}

Como afirma Requena ${ }^{1}$ los omina, muchas veces desdeñados por parte de los historiadores actuales como meras fantasías de los historiadores clásicos, tomaban un papel preponderante dentro del aparato ideológico y propagandístico imperial. Como no podía ser menos, el caso del emperador Vespasiano, debido a la precariedad de su legitimidad en el trono imperial, será un paradigma dentro del uso político de diferentes hechos maravillosos ${ }^{2}$, calculadamente creados y manipulados para crear la seguridad de una sanción divina del poder en la población.

De esta manera, como recoge el autor arriba señalado, los omina no serán más que la reutilización y manipulación de una vía de transmisión del saber de tipo popular para unos fines propagandísticos concretos, quizá más accesibles para el grueso de la población iletrada que las grandes inscripciones circunscritas a cualquier tipo de estructura monumental o una obra literaria de complejo contenido ideológico. En tal sentido podría interpretarse, igualmente, la afirmación que ofrece Tácito (Hist. II,1), en el contexto del viaje de Tito a Roma durante el gobierno de Galba, de la existencia de «[...]la disposición de los espíritus crédulos a tomar por señal del cielo cualquier casualidad. »3

El rumor, extendido por los sectores cercanos al emperador, se filtraría al resto de la población que, al recibir este mensaje propagandístico a través de vías tradicionales de transmisión de la información, podría asimilar y asumir mejor el

\footnotetext{
${ }^{1}$ REQUENA, Miguel, «El emperador predestinado: Los presagios de poder en época imperial romana», Cuadernos de la Fundación Pastor, 2001 (2001), pp. 11-12.

2 FEARS, Rufus, «The Cult of Jupiter and Roman Imperial Ideology» ANRW, 17.1 (1981), pp. 74-75 y VIGOURT, Annie, Les Présages Imperiaux d'Auguste à Domitien. Paris. De Boccard, 2001, p. 9.

${ }^{3}$ Tac. Hist. II,1: «[...] et inclinatis ad credendum animis loco ominum etiam fortuita. [...]».
} 
mensaje del que este es portador. Es la explotación consciente, por tanto, de la credulidad y religiosidad, rayana en la superstición, de la gran masa de población del imperio con un fin concreto: la afirmación del emperador en el poder.

Por tanto, no nos encontramos ante meros relatos de carácter mítico derivados de la fantasía o credulidad de los autores latinos, de meras supercherías e invenciones populares, sino de piezas clave para la compresión de una compleja red de manifestaciones propagandísticas del poder imperial. Dichos portentos obedecerán, de forma inequívoca, a la sanción del emperador por parte de la divinidad, cuyo principal canal de expresión dentro del mundo romano serían los ostenta.

La coincidencia de los temas y divinidades implicadas en los mencionados ostenta con el contexto político y social al cual se ven circunscritos parece indicar en la misma dirección: la creación de un programa propagandístico perfectamente elaborado, destinado a la exaltación del nuevo emperador y a justificar su posición política. Dentro de dicho programa flaviano tendrán especial relevancia, como ya hemos mencionado, tanto la figura de Júpiter Óptimo Máximo, principal deidad del panteón romano, como el del templo erigido en honor de esta divinidad en la colina capitolina, que se verán inmersos en este conjunto de omina de forma recurrente y reiterativa.

Por tanto, la idea que expresa Suetonio en su Vita Vespasiani $(\mathrm{V}, 1)$ de que Vespasiano solo habría concebido la idea de llegar al poder gracias a estos ostenta ${ }^{4}$ es totalmente falsa, al ser una reconstrucción propagandística a posteriori de la vida del nuevo emperador la que llevaría a esta teoría de la predestinación divina de Vespasiano ${ }^{5}$. Es más, la propia matización que hace Tácito en sus Historiae $(\mathrm{I}, 10)$ al afirmar que «las señales y oráculos con que el destino manifestaba su oculto designio de reservar el imperio para Vespasiano y sus descendientes no resultaron creíbles hasta que el desenlace les dio la razón» ${ }^{6}$ podría significar que la creación de estos omina fue construida a posteriori, y que dicha manipulación una vez afirmado el poder era percibida, ya en sus días, por parte de la población mejor preparada intelectualmente ${ }^{7}$.

De esta manera, la continua reelaboración del pasado, la construcción de una biografía mítica del emperador a través de sucesos maravillosos que, al mostrar la voluntad de la divinidad, justificaban su actual acceso al poder, serán una constante en las fuentes literarias que nos hablan del acceso al poder de Vespasiano. Este hecho demuestra, por un lado, el afianzamiento de dichas ideas en el seno de la sociedad romana $y$, por otro, la efectividad y omnipotencia de la maquinaria propagandística imperial.

\footnotetext{
${ }^{4}$ Suet. Vesp. V,1: «[...] in spem imperii uenit iam pridem sibi per haec ostenta conceptam [...]».

${ }^{5}$ VIGOURT, Annie. Op. Cit., p. 161.

${ }^{6}$ Tac. Hist I,10: «[...] occulta fati et ostentis ac responsis destinatum Vespasiano liberisque eius imperium post fortunam credidimus.[...]».

${ }^{7}$ MORGAN, Gwyn, «Omens in Tacitus Histories I-III», en Lorsch, R., y Isager, J., Divination and Portents in the Roman World. Gylling, Odense University Press, 2000, pp. 27-28.
} 
Un elemento añadido por el contexto histórico y político del ascenso al poder del primer emperador flavio, marcado por los conflictos civiles del denominado «Año de los Cuatro Emperadores» y las penalidades a las que el imperio se vio abocado con motivo de los mismos, será la inestabilidad emocional y psíquica de gran parte de la población. Así, la desconfianza hacia la figura imperial, desprestigiada a partir de dichos sucesos, y la sensación de abandono por parte de los dioses serán claves para comprender la efectividad del programa propagandístico flaviano. La desastrosa panorámica trazada por Tácito (Hist. I, 2-3) ${ }^{8}$, autor cercano a la casa imperial Flavia, respecto a este periodo es muy significativa respecto al monstruoso alcance de los acontecimientos, ofreciéndonos la interpretación oficial de los mismos desde una perspectiva propagandística:

"Emprendo un relato cuajado de calamidades, de batallas atroces, de sediciones y revueltas; un tiempo en que hasta la paz fue inmisericorde. A hierro perecieron cuatro emperadores; hubo tres guerras civiles, numerosas en el exterior y a menudo combinadas; la suerte nos fue favorable en Oriente y adversa en Occidente: hubo levantamientos en Ilírico, inestabilidad en las Galias, Britania fue sometida $y$, de inmediato, abandonada; se aliaron en contra nuestra los pueblos sármatas y suevos; del intercambio de derrotas los dacios se ganaron un respeto; a punto estuvieron de levantarse en armas los partos tras el ridículo señuelo de un falso Nerón.

Por su parte, Italia se vio afligida por desastres sin precedente o inusitados desde hacía una larga serie de siglos. Ardieron o quedaron sepultadas las más prósperas ciudades de la costa campana y Roma fue devastada por incendios, los santuarios más antiguos calcinados: las manos de los propios ciudadanos pegaron fuego al Capitolio. Se mancilló lo más sagrado y se ultrajó sin medida. El mar se llenó de exiliados, los escollos de cadáveres. [...]

Junto a las múltiples desdichas de los asuntos humanos, por cielo y tierra se manifestaron portentos, relámpagos ominosos y anuncios del porvenir, sombríos o felices, ambiguos o diáfanos. Y lo cierto es que nunca antes se había probado con desgracias más atroces para el pueblo romano ni señales más precisas que no es misión de los dioses nuestra seguridad, sino nuestro castigo".

De esta manera los acontecimientos acaecidos en el periodo comprendido entre junio del 68 y diciembre del 69 serán interpretados como un castigo divino, como el enfado de la divinidad ante la falta de atención por parte de los mortales

8 Tac. Hist I, 2-3: «Opus adgredior opimum casibus, atrox proeliis, discors seditionibus, ipsa etiam pace saevum. quattuor principes ferro interempti: trina bella civilia, plura externa ac plerumque permixta: prosperae in Oriente, adversae in Occidente res: turbatum Illyricum, Galliae nutantes, perdomita Britannia et statim omissa: coortae in nos Sarmatarum ac Sueborum gentes, nobilitatus cladibus mutuis Dacus, mota prope etiam Parthorum arma falsi Neronis Iudibrio. iam vero Italia novis cladibus vel post longam saeculorum seriem repetitis adflicta. haustae aut obrutae urbes, fecundissima Campaniae ora; et urbs incendiis vastata, consumptis, antiquissimis delubris, ipso Capitolio civium manibus incenso. pollutae caerimoniae, magna adulteria: plenum exiliimare, infecti caedibus scopuli. [...] praeter multiplicis rerum humanarum casus caelo terraque prodigia et fulminum monitus et futurorum praesagia, laeta tristia, ambigua manifesta; nec enim umquam atrocioribus populi Romani cladibus magisve iustis indiciis adprobatum est non esse curae deis securitatem nostram, esse ultionem». 
a sus designios y mandatos. No es, por tanto, una época de crisis provocada por el desgaste del prestigio de la figura imperial y pérdida de control del propio emperador sobre sus dominios en pleno periodo de inestabilidad, sino que se convierte en la señal de los dioses de su descontento hacia el Senado y el Pueblo de Roma por el no cumplimiento de sus deseos.

Los miedos «milenaristas», el terror ante el castigo divino, estaban a la orden del día en una Roma que había perdido todos sus asideros ideológicos. La figura imperial se había devaluado a marchas forzadas, primero con el mal gobierno de Nerón y, después, por el continuo cambio de emperador mediante la usurpación. La sanción divina se había roto, los cultos no se desarrollaban con normalidad y los dioses, como castigo, traían el desastre, la inestabilidad y la destrucción a la vida de los romanos. Se crea, por tanto, un caldo de cultivo idóneo para la preparación psicológica y supersticiosa de la población romana hacia un cambio dinástico, hacia la llegada de un nuevo emperador que, favorecido por los dioses, diese fin a un periodo de tal penuria, inestabilidad y depresión masiva.

Es más, es esta inestabilidad emocional de la población la que propicia, de un modo u otro, la mejor asunción por parte de la misma de los mensajes de conciliación y pacificación sancionados por los dioses creados por el poder. La credulidad exaltada por un periodo de gran inestabilidad sería la que llevase al pueblo a interpretar dichos desastres como castigo divino ${ }^{9}$, como bien percibe Tácito (Hist. IV, 26) al afirmar, con motivo de la reacción de la población ante una bajada de caudal del Rin, que «[...]lo que en tiempos de paz se atribuía a la casualidad o la naturaleza, se llamaba ahora destino o cólera divina.[...]»10

Es curioso el hecho de que un siglo antes Cicerón ya había ofrecido una afirmación muy similar (De Div. II, XXVII, 58) ${ }^{11}$ al decir: «[...]Pero estos efectos, que ni siquiera se observan en tiempo de paz, se aumentan y abultan, gracias al miedo, en tiempo de guerra. Acontece también que el terror y el peligro que preparan los ánimos a creerlos aseguran, al mismo tiempo, la impunidad a los que lo inventan». El conocimiento de este comportamiento por parte de la plebe en tiempos de crisis por parte de las élites por lo menos desde el siglo I a.C. Ilevaría, sin lugar a dudas a la explotación propagandística de dicho proceso.

Así, habría que tener en cuenta que, en el caso que estudiamos, no sólo toma parte la tendencia a la superstición de la religiosidad popular, común a cualquier otro periodo de la historia de Roma, sino una especial predisposición de la población a creer en señales divinas, en providencialismos ficticios que, en último término, consiguiesen librarle de los castigos a los que se había visto abocada irremediablemente. Es esta necesidad de creer en un futuro mejor, en la recuperación del apoyo negado en esos momentos por los dioses, la que convertirá estas anéc-

\footnotetext{
${ }^{9}$ MORGAN, Gwyn. Op. Cit., p. 29

${ }^{10}$ Tac. Hist.IV,26: «[...] quod in pace fors seu natura, tunc fatum et ira dei vocabatur [...]».

${ }^{11}$ Cic. De Div. II, XXVII, 58 «[...] Atque haec in bello plura et maiora videntur timentibus, eadem non tam animadvertuntur in pace; accedit illud etiam, quod in metu et periculo cum creduntur facilius, tum finguntur impunius".
} 
dotas propagandísticas en verdaderas señales celestes. Es, por tanto, el deseo de la recuperación del control de la sociedad por parte de los dioses, que confían en el poder en Vespasiano como su favorito, la que lleva a la población a predisponerse al aparato propagandístico desarrollado por el nuevo emperador.

Por tanto, no sólo el aprovechamiento de este clima psicológico imperante dentro del imperio será posible, sino que se convertirá en primera base del asentamiento de una nueva dinastía rectora en el trono imperial, a pesar de la falta de justificación y sanción de la misma. Las propias afirmaciones de Tácito, en cuanto a los orígenes populares y supersticiosos en la interpretación de señales divinas, indican que, con toda probabilidad, las clases altas cultas podrían haber manipulado dichas señales divinas en su propio beneficio, alejándose de, y a la vez aprovechando, la credulidad imperante en el grueso de la población romana.

Es así una construcción propagandística basada, primordialmente, en la superstición disparada durante el periodo de inestabilidad precedente, el aprovechamiento de la creencia popular en beneficio del nuevo poder impuesto por las armas. Un programa propagandístico perfectamente estructurado en el cual Júpiter Óptimo Máximo, junto a su principal templo, ocuparía, como máxima divinidad de Roma y como garante de la supervivencia del estado, un lugar central dentro de este conglomerado ideológico propagandístico.

\section{LA DESTRUCCIÓN DE JÚPITER ÓPTIMO MÁXIMO COMO CRISIS IDEOLÓGICA Y LA RESTAURACIÓN DEL IMPERIO}

Como ya hemos mencionado anteriormente, fue el clima de grave crisis del sistema imperial iniciado por Augusto, motivada por la caída de la dinastía Julio-Claudia y el posterior periodo de guerras civiles, los que permitieron el afianzamiento de una más que efectiva labor de preparación propagandística del ascenso al poder de la nueva dinastía Flavia, considerándose su advenimiento como el fin de todas las desgracias acaecidas como castigo divino.

Dentro de dicho clima de inestabilidad y crisis psicológica de la población, abandonada a su suerte por los dioses, tendrá una más que especial relevancia el incendio del templo de Júpiter Óptimo Máximo en el Capitolio, representación última de la continuidad de la ciudad bajo la égida de los dioses celestes. Así nos lo confirmará, nuevamente, Tácito (Hist. IV,54) con las siguientes palabras: «[...]Pero nada les había inducido tanto a creer que el fin del imperio era inminente como el incendio del Capitolio. Los galos capturaron antaño la Urbe, pero el imperio sobrevivió porque la morada de Júpiter se había mantenido en pie; ahora, con el fuego, los Hados daban señal de la cólera celeste y de que el dominio del mundo pasaría a manos de los pueblos transalpinos, eso era lo que vaticinaba la huera superstición de los druidas [...]. .12

12 Tac. Hist. IV, 54: «[...] sed nihil aeque quam incendium Capitolii, ut finem imperio adesse crederent, impulerat. captam olim a Gallis urbem, sed integra lovis sede mansisse imperium: fatali nunc igne signum caelestis irae datum et possessionem rerum humanarum Transalpinis gentibus portendi superstitione vana Druidae canebant [...]». 
Dichas consideraciones no son, ni mucho menos, baladíes ya que comparan los hechos en gravedad con la toma de Roma por parte de Breno a principios del siglo IV a.C., hecho histórico traumático donde los haya para la orgullosa urbe. Es más, el Capitolio, salvado de las tropas bárbaras por los defensores romanos, que allí se habían refugiado, sobrevive a tal momento de crisis mientras que, en el año 69 , arde ante los ojos estupefactos de los ciudadanos, verdaderos artífices del desastre en medio del conflicto civil, creando la sensación de desastre inminente y de la destrucción del Estado.

Igualmente se debe tener en cuenta el hecho de que los druidas, relativamente lejanos de la capital, perciben el incendio del templo de Júpiter como la señal inequívoca del fin de Roma, indicando en cierto modo que la asunción del Capitolio como pignor imperii se había extendido incluso a escala provincial y era explotada en dicho sentido por la propaganda druídica ${ }^{13}$.

Este incendio, más allá de la destrucción material, significa la destrucción simbólica de la ciudad ya que el templo, representante último de la supervivencia de Roma bajo la protección de los dioses, representa, en el momento de su desaparición, el declive final de una urbe que, conducida bajo pésimos gobernantes no sancionados por los dioses, ha llegado a su total hundimiento moral, social y político.

No debe extrañar, por tanto, que Tácito (Hist. III,72) afirme que:

«Desde la fundación de la Urbe era lo más funesto y siniestro que había sucedido al Estado del pueblo romano: la morada de Júpiter Óptimo Máximo, que nuestros antepasados fundaron solemnemente como garante del imperio, no había podido profanarla nadie, ni Porsenna tras capitular la ciudad ni los galos tras apoderarse de ella. Ahora, sin enemigo extranjero, propicios, con permiso de la moral de nuestro tiempo, los dioses, la locura de los príncipes bastó para arrasarla. Es verdad que ya antes había ardido el Capitolio durante una guerra civil, pero fue un delito anónimo: ahora a la vista de todos sufrió asedio y a la vista de todos fue incendiado. ¿Con qué interés militar?, ¿qué podía compensar tamaña pérdida?» ${ }^{14}$.

De esta manera, el incendio del Capitolio se producirá cuando Sabino, hermano de Vespasiano y principal defensor de sus intereses en Roma, tras convencer a Vitelio de abandonar el trono imperial, se ve atacado, junto a los principales defensores de Vespasiano, por parte de los Vitelianos cerca el estanque Fundanio. Para huir de dicho ataque, Sabino y los principales flavianos, incluido el propio Domiciano, que se une a los defensores, se refugian en el Capitolio y se preparan para la defensa de la colina. Al día siguiente, los Vitelianos tratan de tomar al asal-

${ }^{13}$ ZECCHINI, Giuseppe., Los druidas. Madrid, Alderabán, 2002, pp. 122-124.

${ }^{14}$ Tac. Hist. III, 72: «Id facinus post conditam urbem luctuosissimum foedissimumque rei publicae populi Romani accidit, nullo externo hoste, propitiis, si per mores nostros liceret, deis, sedem lovis Optimi Maximi auspicato a maioribus pignus imperii conditam, quam non Porsenna dedita urbe neque Galli capta temerare potuissent, furore principum excindi. arserat et ante Capitolium civili bello, sed fraude privata: nunc palam obsessum, palam incensum, quibus armorum causis? quo tantae cladis pretio stetit?[...]». 
to la ciudadela del Capitolio, quemando la puerta principal del recinto sagrado y obligando a Sabino a la mutilación de las estatuas ubicadas en el area capitolina y las techumbres de los diversos templos y dependencias allí ubicados ${ }^{15}$. Poco después, los atacantes empezarían a amenazar a los defensores desde los edificios colindantes, momento en el que, según las fuentes, se desencadena la catástrofe.

Tácito ( Hist. III, 71), por su parte, resume los hechos de la siguiente manera:

«[...] Tampoco podían evitar que se encaramaran a los altos edificios colindantes que, construidos durante el largo periodo de paz, alcanzaban el nivel del suelo del Capitolio. Y aquí hay dudas sobre si fueron los asaltantes los que prendieron fuego a los tejados o si, como cree la mayoría, lo hicieron los asediados para impedir su avance y desalojarlos. A partir de ahí, el fuego se extendió a los soportales anejos al templo, luego a los aguilones que sostenían el frontón, de madera rancia, atrajeron y alimentaron las llamas. $Y$ de este modo el templo capitolino, con las puertas cerradas, sin nadie que lo defendiera y nadie que lo saqueara, ardió como una pira.» ${ }^{16}$

De esta manera, Tácito, dentro de una muestra de imparcialidad ${ }^{17}$, afirma que es bastante probable que fuesen los propios defensores los que, en un intento de librarse del acoso de los sitiadores, incendiasen los edificios colindantes y, con ello, el propio templo de Júpiter, que ardería ante los ojos de los impotentes defensores.

El incendio, ya en un primer momento, causaría una gran impresión e impacto psicológico en los propios defensores del Capitolio, lo cual facilitaría la derrota de los mismos como bien nos relata Tácito (Hist, III, 73):

"El incendio provocó, sin embargo, más pavor entre los sitiados que entre los sitiadores. Lo cierto es que a los soldados vitelianos no les faltaba ni astucia ni valor en medio de la incertidumbre; en cambio entre los soldados del bando adversario reinaba el desconcierto. A su jefe, incapaz de reaccionar y como hipnotizado, de nada le valían lengua u oídos: ni respondía a indicaciones ajenas ni las suyas ter-

15 RICHARDSON, Lawrence, A New Topographical Dictionary of Ancient Rome. London, The John Hopkins University Press, 1992, pp. 31-32.

${ }^{16}$ Tac. Hist. III, 71: «[...] nec sisti poterant scandentes per coniuncta aedificia, quae ut in multa pace in altum edita solum Capitolii aequabant. hic ambigitur, ignem tectis obpugnatores iniecerint, an obsessi, quae crebrior fama, dum nitentis ac progressos depellunt. inde lapsus ignis in porticus adpositas aedibus; mox sustinentes fastigium aquilae vetere ligno traxerunt flammam alueruntque. sic Capitolium clausis foribus indefensum et indireptum conflagravit».

${ }^{17}$ Dicho intento de Tácito de presentar las dos versiones de los hechos, confirmando, a pesar de poner con ello en evidencia a los flavianos, que pudieron ser los propios defensores los que prendiesen fuego accidentalmente al Capitolio, destaca curiosamente con la perspectiva ofrecida por Suetonio, en la que el autor no solo culpa a los Vitelianos del incendio de forma inequívoca sino que, además, presenta al emperador de una forma totalmente impía, como principal instigador del incendio y como regocijado espectador del desastre que acaecía a la ciudad de Roma. «[...] Lanzándose inesperadamente al ataque, obligó a Sabino y a los otros partidarios de Vespasiano, que se creían ya fuera de peligro, a refugiarse en el Capitolio, y, después de incendiar el templo de Júpiter Óptimo Máximo, los pasó a cuchillo. Entre tanto, contemplaba a lo lejos, desde el Palacio de Tiberio, la batalla y el incendio regocijándose con un banquete». En la versión original: «[...] animum resumpsit Sabinumque et reliquos Flavianos nihil iam metuentis vi subita in Capitolium compulit, succensoque templo lovis Optimi Maximi oppressit, cum et proelium et incendium e Tiberiana prospiceret domo inter epulas [...]» (Vesp. 15, 3). 
minaban de concretarse; giraba de un lado a otro al dictado de los gritos del enemigo; prohibía lo que acababa de ordenar, ordenaba lo que acababa de prohibir. Luego, como sucede en las situaciones desesperadas, todos daban instrucciones y ninguno las seguía. Al final arrojaron las armas y ya sólo buscaban la manera de escapar y esconderse» ${ }^{18}$.

La sola visión del Capitolio en llamas sirve para generar la desbandada general de los defensores y el hundimiento de la moral del propio Sabino, que será finalmente capturado y asesinado por la turba enfurecida, que arrastraría su cadáver hasta las escaleras Gemonias ${ }^{19}$. Domiciano, por su parte, se salvará al refugiarse en la casa del aedituus ${ }^{20}$, librándose, en última instancia, de las represalias vitelianas gracias a su huida bajo el disfraz de sacerdote de Isis ${ }^{21}$, como bien recoge Tácito (Hist. III, 74) al afirmar:

"Domiciano, quien a la primera irrupción se había escondido en casa del aedituus, gracias a la astucia de un liberto se mezcló vestido de lino entre una turba de oficiantes y pudo pasar inadvertido hasta guarecerse en la casa de Cornelio Primo, un cliente de su padre, junto al Velabro. "Por eso, durante el gobierno de Vespasiano, hizo derribar el cobertizo del aedituus poniendo en su lugar una modesta capilla dedicada a Júpiter Conservador con un altar donde registró en mármol su pericia. Más tarde, ya emperador, consagró un enorme templo a Júpiter Custodio con una representación suya en el regazo del dios.[...] $]^{22 » .}$

Dicha salvación se reflejará, como afirma Tácito, en la construcción de un sacellum a luppiter Custos en el lugar donde se hallaba la casa del aedituus que le dio refugio. Dicho sacellum, que sería posteriormente ampliado y convertido en

${ }^{18}$ Tac. Hist. III, 73: "Sed plus pavoris obsessis quam obsessoribus intulit. quippe Vitellianus miles neque astu neque constantia inter dubia indigebat: ex diverso trepidi milites, dux segnis et velut captus animi non lingua, non auribus competere, neque alienis consiliis regi neque sua expedire, huc illuc clamoribus hostium circumagi, quae iusserat vetare, quae vetuerat iubere: mox, quod in perditis rebus accidit, omnes praecipere, nemo exequi; postremo abiectis armis fugam et fallendi artis circumspectabant $[\ldots] \gg$.

19 Tac. Hist. III, 74: «[...] Cargados de cadenas, Sabino y Ático fueron conducidos a presencia de Vitelio. Éste los recibió con palabras y gestos en absoluto hostiles, mientras bramaban quienes pedían su ajusticiamiento y el pago de los servicios prestados. Contagiada por el clamor de los implicados, la chusma reclama también la ejecución de Sabino mezclando amenaza y adulación. Vitelio, de pie ante la escalinata del Palacio, estaba dispuesto a interceder, pero le obligaron a desistir: entonces acuchillan, cercenan y decapitan a Sabino y arrastran su cadáver mutilado hasta las Gemonias. [...]”. En la versión original: «[...] Sabinus et Atticus onerati catenis et ad Vitellium ducti nequaquam infesto sermone vultuque excipiuntur, frementibus qui ius caedis et praemia navatae operae petebant. clamore a proximis orto sordida pars plebis supplicium Sabini exposcit, minas adulationesque miscet. stantem pro gradibus $\mathrm{Pa}$ latii Vitellium et preces parantem pervicere ut absisteret: tum confossum laceratumque et absciso capite truncum corpus Sabini in Gemonias trahunt.[...]».

${ }^{20}$ ARATA, Francesco Paolo, «Observazioni sulla topografía sacra dell'Arx Capitolina», MEFRA 122-1 (2010), p.136.

${ }^{21}$ WISEMAN, Timothy Peter., «Flavians on the Capitol» AJAH3-2, (1978), pp. 172-174.

22 Tac. Hist.III, 74: «Domitianus prima inruptione apud aedituum occultatus, sollertia liberti lineo amictu turbae sacricolarum immixtus ignoratusque, apud Cornelium Primum paternum clientem iuxta Velabrum delituit. ac potiente rerum patre, disiecto aeditui contubernio, modicum sacellum lovi Conservatori aramque posuit casus suos in marmore expressam; mox imperium adeptus lovi Custodi templum ingens seque in sinu dei sacravit [...]». 
templo bajo el reinado de Domiciano, consistía en un altar de mármol en el cual se representaba el momento del rescate de Domiciano por parte de la divinidad. Sabemos que, posteriormente, la estatua de culto del templo erigido en el lugar por Domiciano representaría al emperador siendo llevado en brazos por parte de la divinidad, librándole así del peligro que suponían las tropas vitelianas, con lo cual, podemos deducir que el relieve de mármol del primer altar podría seguir una configuración iconográfica similar²3.

Esta predilección de la divinidad por Domiciano, y por extensión a la familia imperial, se verá también reflejada en las monedas, siendo las acuñaciones de lovis Custos una constante durante el periodo de reinado de la dinastía Flavia ${ }^{24}$.

La destrucción del templo es percibida, por tanto, como la mayor de las catástrofes de un periodo de continuas convulsiones y luchas civiles, en las que las matanzas, la escasez y la inseguridad estaban a la orden del día. El templo de Júpiter es visto como un objeto necesario para la continuación del imperio, como parte intrínseca de su misma existencia, y su destrucción resulta, a ojos de los romanos del periodo, el peor castigo que los dioses podían enviar. Su destrucción no es sino la traducción de los años de gobierno de malos emperadores, de usurpadores que, sin contar con la sanción divina necesaria, se ven abocados, al igual que el templo, a la destrucción, no sin antes arrastrar al pueblo de Roma a la ruina.

Por ello, la reconstrucción del templo por parte de Vespasiano se convierte, sin duda alguna, en parte principal de su programa político, arquitectónico y, principalmente, propagandístico. Vespasiano debe mostrarse como un cambio frente a sus predecesores, como el emperador elegido directamente por los dioses para frenar tal cadena de desastres ${ }^{25}$ y devolver a Roma su grandeza perdida a través de la pietas y la recuperación del favor de los dioses. De este modo, un emperador de orígenes poco prometedores, y carente de justificación para acceder al trono más allá de la fuerza de las armas, consigue apropiarse ideológicamente de la principal figura del panteón romano, del dios que encarna en sí mismo a la realeza y la majestad, Júpiter Óptimo Máximo²6.

Por todo ello, la reconstrucción del templo de Júpiter Óptimo Máximo fue prioritaria dentro de la política reconstructiva y propagandística flaviana. De esta manera, la toma de decisiones al respecto comenzará durante la primera reunión del Senado celebrada tras la caída de Vitelio, en la cual, como bien recoge Tácito (Hist IV,4) «[...] volvieron sus ojos a los dioses: se aprobó la restauración del Capitolio» ${ }^{27}$. En la mayor parte de las reuniones recogidas por las fuentes, principalmen-

${ }^{23}$ ARATA, Francesco Paolo. Op. Cit. p. 139; JACOBO, Álvaro, Avctoritas et maiestas. Historia, programa dinástico e iconografía en la moneda de Vespasiano. Alicante, Universidad de Alicante, 2003, p. 90 y .RICHARDSON, Lawrence. Op. Cit., p. 218.

24 JACOBO, Álvaro. Ídem, p. 204.

${ }^{25}$ FEARS, Rufus, «Princeps a diis electus: The divine election of the emperor as a political concept at Rome" Papers and Monographs of the American Academy in Rome. Vol. XXVI. Rome, American Academy in Rome, 1977, p. 192.

${ }^{26}$ VIGOURT, Annie. Op. Cit., pp. 199-200.

${ }^{27}$ Tac. Hist. VI, 4: «[...] Mox deos respexere; restitui Capitolium placuit [...]». 
te por las Historiae de Tácito, se mencionan aspectos relativos a la reconstrucción del templo y sus costes a la vez que se decide otorgar el poder imperial a Vespasiano. En dichas reuniones tendrá una especial relevancia la figura de Domiciano, único miembro de la familia, tras el asesinato de Sabino, presente para defender los derechos de Vespasiano.

Una vez decididos los detalles, se procede a la purificación previa de los restos del templo bajo órdenes de los arúspices el 21 de junio del 70, meses antes de la llegada de Vespasiano a Roma en octubre del mismo año. Tácito (Hist. IV, 53$)^{28}$ recoge en su obra las tareas rituales llevadas a cabo en la colina capitolina antes del inicio de las obras de construcción:

«La tarea de restaurar el Capitolio se la encomienda a Lucio Vestino, un hombre del orden ecuestre, pero cuyo prestigio y reputación le situaban entre los próceres. Los arúspices que convocó le indicaron que los escombros del santuario anterior debían arrumbarse en las marismas y el nuevo templo se levantase sobre sus restos: los dioses no querían que su antigua planta se alterase. El 21 de junio, en un día apacible, todo el espacio que se dedicaba al templo apareció circundado de cintas y guirnaldas. En él hicieron su entrada soldados con nombres propicios portando ramas de buena ventura. Detrás, las vírgenes vestales, junto a un cortejo de niños y niñas cuyos padres y madres aún vivían, rociaron el recinto con agua procedente de manantiales y ríos. A continuación el pretor Helvidio Prisco, dirigido por el pontífice Plaucio Eliano, lo purificó mediante el sacrificio de un cerdo, un cordero y un buey, esparciendo después sus entrañas sobre un altar de césped. Tras impetrar a Júpiter, Juno y Minerva, dioses protectores del imperio, que la obra emprendida llegase a buen fin y bendijesen con su divino sufragio aquella morada iniciada por la devoción de los hombres, tocó las cintas que ceñían la piedra ceremonial y anudaban las sogas. En ese momento los demás magistrados y sacerdotes, senadores, caballeros y una gran parte del público, con esfuerzo y entusiasmo combinados, arrastraron la enorme roca. A los cimientos se arrojaron con profusión piezas de oro y plata así como fragmentos de metal no sometidos al horno, sino en su estado original: los arúspices habían prescrito que la obra no debía contaminarse con piedra u oro destinado a otro propósito. Se elevó la altura del edificio: al parecer, ésa era la única modificación que admitía el culto y faltaba a la magnificencia del templo anterior».

28 Tac. Hist. IV, 53: «Curam restituendi Capitolii in Lucium Vestinum confert, equestris ordinis virum, sed auctoritate famaque inter proceres. ab eo contracti haruspices monuere ut reliquiae prioris delubri in paludes aveherentur, templum isdem vestigiis sisteretur: nolle deos mutari veterem formam. XI kalendas lulias serena luce spatium omne quod templo dicabatur evinctum vittis coronisque; ingressi milites, quis fausta nomina, felicibus ramis; dein virgines Vestales cum pueris puellisque patrimis matrimisque aqua e fontibus amnibusque hausta perluere. tum Helvidius Priscus praetor, praeeunte Plautio Aeliano pontifice, lustrata suovetaurilibus area et super caespitem redditis extis, lovem, Iunonem, Minervam praesidesque imperii deos precatus uti coepta prosperarent sedisque suas pietate hominum inchoatas divina ope attollerent, vittas, quis ligatus lapis innexique funes erant, contigit; simul ceteri magistratus et sacerdotes et senatus et eques et magna pars populi, studio laetitiaque conixi, saxum ingens traxere. passimque iniectae fundamentis argenti aurique stipes et metallorum primitiae, nullis fornacibus victae, sed ut gignuntur: praedixere haruspices ne temeraretur opus saxo aurove in aliud destinato. altitudo aedibus adiecta: id solum religio adnuere et prioris templi magnificentiae defuisse credebatur». 
Como podemos observar el rito de purificación sigue unas normas estrictas destinadas a propiciar la buena marcha de las obras de reconstrucción mediante símbolos de pureza. A tal respecto cabe destacar las vírgenes vestales, los soldados con nombres propicios o los niños de padres aún vivos a nivel personal y el agua de manantiales y ríos, símbolo de pureza frente al agua de pozo o de lluvia, y de metales sin trabajar a escala material. Es, por tanto, el intento ritual de superar, de algún modo, la tremenda irreverencia a los dioses cometida con motivo del incendio del Capitolio, un intento de paliar la cólera divina ante el hecho más luctuoso acaecido en el seno de la ciudad de Roma.

Por otro lado, también destaca la idea de permanencia de la tradición, con la prohibición expresa de cambiar la planta del templo, obligando a atenerse la nueva construcción a los antiguos cimientos. Dicho conservadurismo no es baladí, sino que justifica la nueva construcción como heredera de la anterior, como nueva depositaria del destino del pueblo romano. A pesar de ello, se permitirá elevar el templo, que para aquellas fechas no sería tan visible para la población debido a la profusa aparición de edificaciones en los alrededores del Capitolio. Este hecho podría estar relacionado, con toda seguridad, con el programa ideológico y propagandístico flaviano: no sólo se construye lo destruido, sino que se construye con mayor riqueza y grandeza; es el renacer de Roma en una nueva edad de oro tras años de decadencia y destrucción.

A pesar de no participar en los ritos propiciatorios, y conociendo perfectamente el gran alcance propagandístico que suponía la reconstrucción del templo de Júpiter dentro de la mentalidad romana, Vespasiano participará directamente en las tareas de reconstrucción del templo a su vuelta de Oriente, llegando a afirmar Suetonio (Vesp.VIII,5) 29: «Él mismo, al iniciar la reconstrucción del Capitolio, fue el primero que puso manos a la obra en la retirada de los escombros y cargó sobre sus hombros algunas espuertas".

Por tanto, la reconstrucción del templo se hará esperar varios meses, hasta la llegada de Vespasiano, para permitir que el emperador mismo sea el que inicie el proceso de reconstrucción, participando en el desescombro de la zona del templo. Dicha imagen será completamente beneficiosa para el emperador, mostrándose a sí mismo como adalid de la pietas hacia los dioses y como reconstructor personal y garante último de la grandeza de Roma. Es, por tanto, una potente imagen propagandística, la justificación ideológica a través de la sanción divina de una nueva dinastía llegada al trono, al igual que Galba, Otón y Vitelio, a través de la usurpación, pero destinada por los dioses a la recuperación de la ciudad tras el periodo de crisis más acusado de su historia.

De igual manera, llevará a cabo diversos actos de índole práctica, como la restauración integral de los documentos custodiados en el Capitolio y destruidos por el incendio ${ }^{30}$, como recoge Suetonio $(\mathrm{VIII}, 5)$ :

${ }^{29}$ Suet. Vesp. VIII, 5: «[...] Ipse restitutionem Capitolii adgressus, ruderibus purgandis manus primus admovit ac suo collo quaedam extulit [...]».

${ }^{30}$ LEVICK, Barbara. Vespasian. London, Routledge, 1999, p. 126. 
«[...] Dispuso también que se reprodujeran tres mil tablas de bronce que habían ardido junto con el Capitolio, para lo cual hizo buscar las copias por doquier. Eran, en efecto, unos documentos de un valor inapreciable y los más antiguos del Imperio, pues contenían, casi desde la fundación de Roma, los decretos del Senado, los plebiscitos concernientes a las alianzas, tratados de paz y privilegios acordados a quienquiera que fuera [...]».

Y es que el Capitolio, además de centro religioso de Roma, donde los cónsules ofrecen sus primeros sacrificios públicos, el Senado se reúne en asamblea solemne y termina la pompa triumphalis, también era el archivo donde se depositaban los documentos relacionados con la política exterior desde época republicana, incluyendo los tratados de diferente tipo ${ }^{31}$.

Respecto a la financiación del proyecto tenemos constancia de que el fiscus iudaicum, al menos en un principio, se destinó íntegramente a la reconstrucción del templo de Júpiter Óptimo Máximo gracias a Flavio Josefo, que en la Guerra de los Judíos (VII, 218) afirma: «Por otra parte, impuso a los judíos, en cualquier sitio donde estuvieran, un impuesto de dos dracmas cada uno que ordenó entregar todos los años al Capitolio, como antes lo habían hecho en el Templo de Jerusalén. Esta era la situación de los judíos en aquel momento ${ }^{32}$ ».

Dicha medida, por otra parte totalmente hiriente para el pueblo judío ${ }^{33}$, constituía, a la vez que se castigaba a los rebeldes judíos, una nueva fuente de ingresos en un momento débil para las arcas imperiales, prácticamente vacías tras el cruento periodo de guerras civiles. A pesar de ello, según puede desprenderse de Tácito (Hist. IV, 9) ${ }^{34}$, Vespasiano llegaría incluso a poner su propio dinero, además del proveniente del Estado: «[...] Había propuesto Helvidio que la restauración del Capitolio fuese costeada con dinero público y Vespasiano contribuyese: los más moderados dejaron pasar esa opinión en silencio y después se olvidó. Otros hubo, sin embargo, que la recordasen».

Otra de las noticias que han llegado a nosotros respecto a la reconstrucción del templo de Júpiter tiene un carácter casi anecdótico. Suetonio (Vesp. XVIII, 1$)^{35}$ recoge este hecho de la siguiente manera: «[...] a un ingeniero que le prometía transportar al Capitolio enormes columnas con escaso gasto, le otorgó una re-

${ }^{31}$ BALL PLATNER, Samuel, A Topographical Dictionary of Ancient Rome. Roma, L'Erma di Bretschneider, 1965, p. 302.

${ }^{32}$ Según la Biblia todo judío adulto tenía que pagar el impuesto de medio siclo para contribuir al mantenimiento del Templo; cf. Éxodo 30,13; Nehemías 10, 32; Mateo 17,24 y Antigüedades XVIII 312. Roma mantiene este ficsus iudaicus y lo transfiere al templo de Júpiter Capitolino, ya que el templo de Yahveh ha desaparecido. Domiciano cometió una serie de abusos en la percepción de este impuesto, como mencionan Suetonio Dom. XII y Dión Caiso. LXVI, 7.

${ }^{33}$ FERNÁNDEZ-ARDANAZ, Santiago y GONZÁLEZ FERNÁNDEZ, Rafael, «El fiscus iudaicus y las posiciones políticas de los cristianos de Roma bajo Domiciano» Gerión 23, 1, (2005), pp. 219-232.

${ }^{34}$ Tac. Hist. IV, 9: «[...] Ensuerat Helvidius ut Capitolium publice restitueretur, adiuvaret Vespasianus. eam sententiam modestissimus quisque silentio, deinde oblivio transmisit: fuere qui et meminissent».

${ }^{35}$ Suet. Vesp. XVIII,1: «[...] mechanico quoque, grandis columnas exigua impensa perducturum in Capitolium pollicenti, praemium pro commento non mediocre optulit, operam remisit, praefatus sineret se plebiculam pascere». 
compensa pingüe por el invento, pero no quiso ponerlo en práctica alegando que le dejara dar de comer a la plebe desvalida». Dicha afirmación ha sido difamada en alguna ocasión al considerar que las obras del templo serían llevadas a cabo por artesanos especializados, más teniendo en cuenta la carestía de los materiales utilizados para la reconstrucción, entre los cuales se encontraba el mármol del Pentélico del cual estaban realizadas las columnas aquí mencionadas ${ }^{36}$. Sin embargo, no hay motivos para pensar que en la reconstrucción se utilizasen, en forma de peones no cualificados dedicados a las tareas de desescombro, elementos pertenecientes a las clases bajas de la ciudad, en un gesto populista del nuevo emperador.

Como conclusión, y a la luz de los datos aportados, Vespasiano, hábil político, aprovecha, sin lugar a dudas de forma premeditada, una crisis psicológica general del mundo romano, inmerso en un largo año de contiendas civiles tras el desastroso gobierno de Nerón, para asentar su propio poder. Como ya hemos dicho que afirmaba Tácito (Hist. IV,26) las crisis hacen ver predestinación, voluntad divina o castigo celestial lo que en tiempos de bonanza se toman como simples casualidades. El aprovechamiento propagandístico de la reconstrucción del templo de Júpiter, como máximo exponente de los desastres de la guerra y del castigo divino por la impiedad del pueblo romano, será un arma formidable que Vespasiano no dudará en utilizar propagandísticamente a lo largo de su reinado para asentar su poder y el de su dinastía.

\section{LOS OMINA IMPERII DE VESPASIANO Y JÚPITER: UNA JUSTIFICACIÓN RELIGIOSA}

Como no podía ser de otro modo, el advenimiento al poder de Vespasiano será reforzado por determinados omina imperii que, creados a posteriori, fueron la base perfecta para el establecimiento de un poder sancionado por la divinidad misma. La propia destrucción y posterior reconstrucción del templo de Júpiter Óptimo Máximo, unido a la grave crisis psicológica desatada con motivo del «año de los cuatro emperadores» y los desastres de las guerras civiles, darán a Vespasiano la oportunidad de vincular su advenimiento al poder con el propio Júpiter Capitolino.

La elección de dicha divinidad, en paralelo, también está en relación con la estrecha afinidad de tal deidad con la casa imperial, siendo el representante celeste del poder. No son pocas las acuñaciones que muestran al propio Júpiter, como verdadero depositario del poder, entregar las insignias imperiales al nuevo dirigente ${ }^{37}$. Así, la utilización de Júpiter fue bastante frecuente en anteriores reinados, haciendo que la propaganda flaviana, si bien potenciadora de los mensajes en tal sentido, recogiese una tradición perfectamente asentada y, por ello, más aceptable para la población.

${ }^{36}$ BALL PLATNER, Samuel. Ibídem., p. 300. 
Sin embargo, Vespasiano relacionará muchos de estos presagios con la figura de Nerón, ya que si bien la visión aportada por las fuentes de este emperador es sumamente negativa fue, al fin y al cabo, el último emperador de la dinastía JulioClaudia y, por tanto, el último depositario legal del poder imperial antes de las usurpaciones. De este modo, algunos de los principales omina imperii de Vespasiano, incluidos aquellos relacionados a su vez con Júpiter Óptimo Máximo, serán ambientados durante el reinado de Nerón, del cual Vespasiano, por intermediación de Júpiter, sería el receptor del poder imperial legítimo.

Uno de ellos es recogido por Suetonio (Vesp. V, 7) ${ }^{38}$, el cual refleja un rumor que, supuestamente, recorría la Roma Flavia y que es de gran interés para nuestro estudio. Dice lo siguiente: «También en Roma corrían presagios de boca en boca: que Nerón, en sus últimos días, había sido advertido por un sueño de que sacase la carroza sagrada de Júpiter Óptimo Máximo del santuario donde se guardaba y la trasladara a casa de Vespasiano y de allí al Circo».

Otra versión, más reducida, es recogida en el epítome de Dión Casio (H.R. LXV; 1, 3). Asistimos, por tanto, a la entrega, por parte de Nerón, de un objeto intrínsecamente relacionado, por un lado, con Júpiter Óptimo Máximo y, por otro, con el poder imperial.

Autores como Graf ${ }^{39}$, consideran que dicho omina está relacionado con la pompa triumphalis y, con ello, con la idea de victoria sobre todos los enemigos de Roma y el entronque con la familia Julio Claudia mientras que Mooney lo relaciona con la pompa circensis y, junto con Braithwaite ${ }^{40}$, afirma que esta relación indicaría una atención especial por parte de Júpiter, propietario del carro, sobre la figura de Vespasiano. Si bien Requena ${ }^{41}$ interpreta ambas afirmaciones como confrontadas, podemos afirmar, a la luz de la información referente al uso de Júpiter por parte de Vespasiano y a su afán de entroncar su nueva dinastía con la dinastía Julio-Claudia, que las mismas, son complementarias y, con seguridad, totalmente ciertas. En dicho sentido parece indicar Krauss, para quien la entrega de la thensa significa que el auriga designado por Júpiter es Vespasiano, el cual también debía tomar las riendas del estado ${ }^{42}$.

Aún así el recorrido de la tensa o carro sagrado en la pompa circensis consistía en el mismo tramo que la ceremonia de triunfo, con lo que, al igual que en el momento del triunfo, el emperador era directamente relacionado con la divinidad ca-

${ }^{37}$ REQUENA, Miguel, Op. Cit., p. 29.

${ }^{38}$ Suet. Vesp V, 7: «[...] Nuntiabantur et ex urbe praesagia, Neronem diebus ultimis monitum per quietem, ut tensam lovis Optimi Maximi e sacrario in domus Vespasiani et inde in circum deduceret [...]".

${ }^{39}$ GRAF, Heinz Richard, Kaiser Vespasian. Untersuchungen zu Suetons Vita Divi Vespasiani. Stuttgart, Kohlhammer, 1937.

${ }^{40}$ MOONEY, George W., C. .Suetoni Tranquilli de Vita Caesarum. London, Longmans, 1930, p. 401 y BRAITHWAITE, Alfred William., C. Suetoni Tranquilli. Divus Vespasianus, Oxford, Clarendon Press, 1927, p. 34.

${ }^{41}$ REQUENA, Miguel. Op. Cit., p. 32.

42 KRAUSS, Franklin Brunell, An Interpretation of the Omens, Portents, and Prodigies recorded by Livy, Tacitus, and Suetonius, Philadelphia, Pa. 1930, pp. 152-153. 
pitolina, llevando incluso los atavíos característicos de la misma. Es más, la propia ubicación del carro en la aedes Thensarum ${ }^{43}$, sito en un anexo del templo de Júpiter Óptimo Máximo en el Capitolio, plantea la misma idea, la identificación de Vespasiano con los deseos del propio Júpiter, equiparandose, en cierto modo, Vespasiano a la divinidad.

Por otro lado, sabemos que, en época imperial, el encargado de dirigir la tensa durante la pompa circensis era el emperador, frente a la costumbre republicana de ser conducida por uno de los cónsules ${ }^{44}$. De este modo, el traspaso del carro de Júpiter de manos de Nerón a Vespasiano significa, nada más ni nada menos, que el trasvase de poder, a través de la divinidad, del poder legítimo y legal de la dinastía Julio-Claudia, de la cual Nerón era el depositario último.

Respecto a este omen del carro de Júpiter, Requena niega la afirmación de Lorsch, al considerar que la suposición de que era el emperador el encargado de dirigir la Thensa durante los juegos circenses es falsa y sin fundamento y que la entrega del carro de Júpiter está relacionado más con la entrega de los pignora imperii a Vespasiano que con la entrega de las riendas del carro de Júpiter. Dicha opinión se ve reforzada por la existencia de diversas emisiones monetales en las que se observa a Vespasiano como receptor del palladium, uno de los principales pignora imperiit5.

A pesar de ello, la relación de Júpiter con el omen es indiscutible, siendo señalado por las propias fuentes la importancia de la figura de la divinidad en el sueño de Nerón y no resaltando, en ningún momento, la importancia de los pignora imperii que, además, estarían custodiados por las vestales y no en el carro de Júpiter, conducido por Nerón. Por otro lado, si bien es cierta la afirmación de la existencia de emisiones monetales en las cuales Vespasiano es el receptor de palladium, no son menos las emisiones relacionadas con el templo de Júpiter Óptimo Máximo o, como ya veremos, con la propia thensa de Júpiter, con lo que sería más coherente con la línea propagandística general el pensar en la relación de Vespasiano con el templo de Júpiter y no con los pignora imperii.

Es más, podría llegar a pensarse que la existencia de dichas emisiones con el palladium no responderían a este omen, como afirma Requena, sino que estarían relacionadas con la idea de la restauración de la eternidad de Roma, muy presente igualmente tanto en las fuentes como en las emisiones monetales.

Por otro lado, el águila, símbolo de Júpiter por antonomasia ${ }^{46}$, está presente tanto en las emisiones monetales como en los omina presentes en las fuentes. Así,

${ }^{43}$ STEINBY, Eva Margareta (Ed.) LTUR. Roma, Quasar, 2000. Tomo I. p.17.

${ }^{44} \mathrm{LORSCH}$, Robin Stacey, Omina Imperii. The omens of power received by the Roman emperors from Augustus to Domitian. Their religious iruerpretation and political influence. Chapel Hill, University of North Carolina, 1993, pp. 119-124.

${ }^{45}$ REQUENA, Miguel. Op. Cit, pp. 34-38.

${ }^{46}$ MONTERO, Santiago, Augusto y las aves. Las aves en la Roma del Principado: prodigio, exhibición y consumo. Barcelona, Universitat de Barcelona, 2006, pp. 167-168. 
el propio Suetonio (Vesp. $V, 7)^{47}$ recoge, entre los principales omina imperii del periodo, el vaticinio, a través de águilas, de la toma del poder de Vespasiano tras las guerras civiles del siguiente modo: «[...] que en la batalla de Bedriaco, antes de que se entablara el combate, dos águilas pelearon encarnizadamente a la vista de todos y que, vencida una de ellas, apareció una tercera procedente de Oriente y ahuyentó a la vencedora».

Nos hallamos, por tanto, ante un presagio propiciado por Júpiter a través de su animal representativo, el águila, que, como ya hemos mencionado, estará igualmente presente en gran parte de las emisiones monetarias del reinado y ya tenía una larga tradición desde época republicana y augustea ${ }^{48}$.

Respecto a la vinculación a la familia Julio-Claudia, los omina imperii de Vespasiano, en un intento de entroncar a la nueva dinastía con la legitimidad imperial, obvian a Galba, Otón y Vitelio y ponen en relación directa a Vespasiano con la dinastía de Augusto. Así, Suetonio, debido a su gran riqueza en cuanto a omina se refiere, señala diversos sucesos que ponen en relación directa a Vespasiano con la familia Julio Claudia: «[...] Más tarde, cuando Vespasiano era edil, G. César, indignado por el poco celo que ponía en la limpieza de las calles, ordenó a sus soldados que le cubriesen de barro y, como éstos se lo echaron en el regazo de la toga, no faltaron quienes interpretaron este incidente como un augurio de que, en un futuro no lejano, el Estado, pisoteado y desamparado a consecuencia de una reyerta entre los ciudadanos, iría a ponerse bajo su tutela y, por así decir, a refugiarse en su regazo [...]» (Vesp.V,3) ${ }^{49}$ «[...] Por su parte, Vespasiano soñó en Grecia que se iniciaría la prosperidad para sí y para los suyos no bien arrancasen un diente a Nerón, y aconteció que, al día siguiente, al entrar en el atrio, un médico le mostró un diente que acababa de extraerle [...]» (Vesp. V,5) «[...] la estatua del divino Julio se había vuelto, por impulso, hacia Oriente [...]» (Vesp. V,7 $)^{51}$.

En todas ellas vemos claramente el intento de entroncar a Vespasiano con la anterior dinastía, siéndole entregado el poder por voluntad de los dioses a través de distintos miembros de la misma. Así Calígula, al cubrirle de barro por su mala gestión como edil, en realidad está entregando, en su regazo según Suetonio, el gobierno de Roma, que pisoteado como el barro por las contiendas civiles iría a caer en sus brazos auxiliadores gracias a la voluntad divina ${ }^{52}$. Es, por tanto, una

${ }^{47}$ Suet. Vesp. V, 7: «[...] acieque Betriacensi, prius quam committeretur, duas aquilas in conspectu omnium conflixisse, victaque altera supervenisse tertiam ab solis exortum ac victricem abegisse».

${ }^{48}$ VIGOURT, Annie. Op. Cit., p. 97, 136-137.

${ }^{49}$ Suet. Vesp. V, 3: «[...] Mox cum aedilem eum C. Caesar, succensens curam verrendis viis non adhibitam, luto iussisset oppleri congesto per milites in praetextae sinum, non defuerunt qui interpretarentur, quandoque proculcatam desertamque rem $p$. civili aliqua perturbatione in tutelam eius ac velut in gremium deventuram $[\ldots]$ ».

50 Suet. Vesp. V,5: «[...] At in Achaia somniavit initium sibi suisque felicitates futurum, simul ac dens Neroni exemptus esset; evenitque ut sequenti die progressus in atrium medicus dentem ei ostenderet, tantumque quod exemptum [...]».

51 Suet. Vesp. V,7: «[...] statuam Divi lulii ad Orientem sponte conversam [...]»

52 VIGOURT, Annie, Op.Cit. pp. 260-261. 
construcción ideológica en la cual la justificación del poder, de una forma u otra, es relacionada con determinadas anécdotas, ficticias o reales, que correrán como un rumor por toda Roma dentro de una estrategia propagandística de tipo viral.

En cuanto al diente de Nerón, nos encontramos con un caso similar. La interpretación del prodigio es ofrecida a Vespasiano por la propia divinidad durante el sueño y recaba, de nuevo, en el hecho de la entrega de un objeto relacionado con la antigua dinastía Julio-Claudia, que vendrá a representar la entrega de poder imperial en sí mismo. La simbología de los dientes como objeto de poder es bien descrita por Vigourt y Requena en sus estudios, y refuerzan esta idea de entronque con la dinastía anterior a través de la intercesión divina ${ }^{53}$.

En la misma línea podría interpretarse el giro espontáneo, durante el segundo consulado de Galba, de la estatua del Divino Julio hacia Oriente, señal inequívoca de la aceptación de este fundador dinástico divinizado de la autoridad imperial conferida, por deseo de los dioses, a aquel llegado de Oriente, Vespasiano ${ }^{54}$. Y es que la relación de Vespasiano con Oriente es también clara dentro de los presagios de poder, siendo este su centro inicial de ascenso al poder y, por tanto, lugar de referencia de diferentes omina imperii, como los recogidos por Suetonio (VIII, 1-3) en referencia a su estancia en Alejandría.

Por tanto, la figura de Júpiter, tradicionalmente relacionada con el gobierno de la urbe, toma, durante el reinado de Vespasiano, un papel fundamental dentro del aparato propagandístico del Estado. La quema del templo de Júpiter Óptimo Máximo y, sobre todo, su reconstrucción por parte de Vespasiano, marcan un antes y un después en la historia de la ciudad, inaugurando un nuevo periodo de prosperidad, una nueva edad de oro comparable y equiparable a la augustea según la propaganda, tras uno de los peores periodos de crisis de los que se tenía memoria ${ }^{55}$.

Los omina imperii, en este contexto, funcionan como una forma viral de propaganda, en la que la vía tradicional de trasvase de información entre las clases bajas, el chisme, el cotilleo o el rumor, se usa como canal de penetración del mensaje imperial. De este modo, no solo las grandes empresas arquitectónicas o las obras literarias de alto nivel cultural, destinadas a las élites, funcionarán como soportes propagandísticos, sino que el rumor, perfectamente creado y canalizado por los agentes del emperador, llevará a la convicción, por parte de la población, de la idoneidad del nuevo gobernante apoyado por los dioses y poseedor de la legitimidad imperial perdida, de la cual Nerón, como miembro de los Julio-Claudio, era el último depositario.

${ }^{53}$ REQUENA, Miguel. Op. Cit., pp. 26-30 y VIGOURT, Annie, Ídem, p. 358.

${ }^{54}$ VIGOURT, Annie. Ídem, p. 104, 109, 357.

${ }^{5}$ CRIADO, C., «Júpiter, emperador romano: La lectura política de la Tebaida de Estacio», Minerva. Revista de Filología Clásica 14, (2000), p. 90. 
Por ello, podemos afirmar, sin duda alguna, que el programa propagandístico de Vespasiano, se basará principalmente en la figura de Júpiter como verdadera imagen del poder terrenal y celestial y en la familia Julio-Claudia, como depositaria legal de dicho poder. Es la voluntad de los dioses, demostrada a través de los omina, la que lleva a Vespasiano al poder, no la fuerza de las armas, desmarcándose claramente de sus inmediatos predecesores, Galba, Otón y Vitelio, que serán representados como usurpadores, en contra de la voluntad divina, y culpables, en última instancia, de todos los males acaecidos durante el año 69, incluida la destrucción del recinto sacro por excelencia, el templo de Júpiter Capitolino.

\section{JÚPITER Y LA AMONEDACIÓN DE VESPASIANO: PROPAGANDA E ICONOGRAFÍA MONETARIA}

Como ya hemos visto en los anteriores apartados, la reconstrucción del Capitolio, tras su ignominiosa destrucción hacia el fin de las contiendas civiles, será una de las bases para la propaganda flaviana. La extensión de dicho mensaje propagandístico justificador del poder imperial de una dinastía que, en realidad, había llegado al poder mediante la usurpación, se realizaría, según hemos visto anteriormente, por distintos canales de comunicación. Uno de ellos, la emisión monetaria, resulta realmente interesante para nuestro estudio ya que, además de darnos datos sobre el aspecto del propio templo de Júpiter una vez reconstruido, nos habla del programa político-propagandístico del emperador, al ser elegidos unos determinados tipos monetales en detrimento de otros.

Por otro lado, y como afirma Charlesworth ${ }^{56}$, las monedas eran un elemento primario para la difusión de la información propagandística, como implicaba su misma naturaleza. Las monedas pasan de mano en mano a través de todas las clases sociales a lo largo de todo el imperio, mostrando las imágenes propagandísticas creadas por el poder a gran cantidad de personas por cada moneda acuñada. En el mismo sentido se podrían interpretar las afirmaciones de West ${ }^{57}$, quien afirmaba, igualmente, la importancia de la moneda como difusora de la información entre las masas con el fin de influir la opinión de las mismas hacia una posición concreta determinada por la voluntad del poder que ha creado dichas imágenes iconográficas. A pesar de ello, es probable que, como afirma Levick ${ }^{58}$, no fuese el propio emperador el que diseñase los tipos, sino que serían creados por un equipo especializado siguiendo unas directrices básicas dadas y bajo la aceptación imperial.

\footnotetext{
${ }^{56}$ CHARLESWORTH, Martin Percival, «The virtues of a Roman Emperor. Propaganda and the Creation of Belief» Proceedings of the British Academy 23, (1937), pp. 110-114.

57 WEST, Louis. C., «Imperial Publicity on Coins of the Roman Emperors» Classical Journal 45, (1949), p. 19.

${ }^{58}$ LEVICK, Barbara, «Propaganda and Imperial Coinage», Antichthon 16, 1982, p. 107.
} 
Por ello, las emisiones de monedas en las que aparece el templo de Júpiter, el propio Júpiter o alguno de sus símbolos más representativos, como el águila, parecen indicar en las misma dirección que los omina imperii: el poder de Vespasiano se basa en el apoyo incondicional al mismo por parte de Júpiter, dispensador último del poder imperial y responsable de su ascenso al poder como continuador de la legitimidad imperial perdida y, por ello, su programa iconográfico monetal seguirá las mismas directrices que el resto de los medios de expresión de la propaganda flaviana. De esta manera, se alcanzaría la unidad y coherencia del mensaje emitido por el poder imperial, lo cual favorecería su adopción por parte de los receptores de dicha información propagandística.

A su vez, como bien afirma $A$. Jacobo, le reconstrucción del templo de Júpiter no sólo señalaba a Vespasiano como el elegido por la divinidad para la reconstrucción de Roma, sino que a su vez lo convertía en el adalid de la tradición romana y en garante último de la perpetuidad de la misma. Así, a la vez que se conmemora la reconstrucción del templo de Júpiter Óptimo Máximo, como expiación de los males cometidos durante la contienda por los usurpadores de un poder divino conferido por la deidad, se producen emisiones monetales con las leyendas ROMA PERPETUA o ROMA RESURGENS, que hacen especial hincapié en la inmortalidad del pueblo romano y en la vuelta a una nueva edad de oro, a la restauración de un poder imperial legítimo emponzoñado tras las contiendas civiles.

Es también llamativa la iconografía de dichas monedas, en las cuales Vespasiano, como nuevo emperador, ofrece la mano a la diosa Roma, tendida en el suelo debido a la inestabilidad de las guerras civiles, en el caso de la leyenda ROMA RESURGENS ${ }^{59}$, y la representación de Roma sentada, con traje militar y victoriola en su mano derecha y parazonium, relacionando la victoria de Vespasiano sobre sus enemigos con la propia continuidad de la urbs, en el caso de los tipos de ROMA PERPETUA ${ }^{60}$.

En la misma dirección podrían considerarse las emisiones con la leyenda $A E-$ TERNITAS P.R., en las que aparece Vespasiano recibiendo de una victoria alada el palladium, uno de los principales pignora imperi $^{1}$. Dicha imagen representa, con claridad, la concepción de Vespasiano como salvador del pueblo romano, como el elegido por los dioses para asegurar su continuidad justo después de lo que parecía, a todas luces, su total colapso.

Por otro lado, también la figura de IOVIS CUSTOS ${ }^{62}$ será preeminente en la amonedación de Vespasiano, como protector, por un lado, de la figura imperial frente a los intentos de usurpación o magnicidio por parte de contrincantes políticos, sentido en el cual se utilizó bajo el gobierno de Nerón, o, en caso de Vespasiano, por la protección que dicha divinidad ejerció sobre su hijo Domiciano durante

\footnotetext{
${ }^{59}$ BMC II Vesp. 566

${ }^{60}$ BMC II Vesp. 423

${ }^{61}$ REQUENA, Miguel. Op Cit. pp. 38-39.

${ }^{62}$ BMC II Vesp. 276
} 
el ataque viteliano al Capitolio, como recogimos más arriba. Es de destacar que, si bien el tipo de las monedas es similar a las amonedaciones neronianas, la leyenda es modificada intencionalmente, pasándose de IUPPITER CUSTOS de Nerón al más arcaizante IOVIS CUSTOS flavio, en un intento de diferenciar el gobierno de la nueva dinastía del desastroso gobierno del último de los Julio-Claudios ${ }^{63}$. A pesar de ello, algunos autores también pondrán en relación dicho tipo, y los años en los que este se acuña 75 y 76 d.C., con los complots contra el emperador que Suetonio (Vesp. XXV) ${ }^{64}$ cita al decir: «Todos concuerdan en afirmar que tenía tal confianza en su propio horóscopo y en el de los suyos que, a pesar de las continuas conspiraciones tramadas contra su vida, se atrevió a afirmar en el Senado que le sucederían sus hijos o nadie [...]».

Sea de una manera o de otra la leyenda IOVIS CUSTOS representa, nuevamente, la especial relación del emperador, y su dinastía, con la principal divinidad del panteón romano que, a su vez, era la depositaria del poder imperial y la encargada, en última instancia, de elegir a los gobernantes según su voluntad a través de su apoyo o su castigo. Del mismo modo, el águila, animal por antonomasia de Júpiter, también será representada en las monedas, destacando nuevamente la proximidad a la divinidad ${ }^{65}$. Es, por tanto, una nueva pieza de un entramado propagandístico no abandonado a la casualidad, sino perfectamente estudiado y preparado por parte del nuevo poder imperial.

Por otro lado, debe mencionarse la existencia de un aureo póstumo de Vespasiano, datado en el $80^{66}$, identificable con el omen de la entrega del carro de Júpiter por parte de Nerón, ya que muestra la thensa tirada por cuatro caballos y coronada con dos victorias aladas. Dicha moneda confirmaría la existencia de un programa iconográfico y propagandístico perfectamente diseñado en el cual el mensaje ideológico deseado por el poder llegaría a la población a través de diferentes vías de penetración.

Sin embargo, el tipo más representativo de dicha política será, sin lugar a dudas, el del propio templo de Júpiter Óptimo Máximo ${ }^{67}$. El templo hexástilo sobre un podio de cuatro escalones será representado con sus puertas abiertas, mostrando las divinidades custodiadas en su interior: Júpiter entronizado con cetro en la nave central, Juno, a la derecha, con cetro y Minerva, a la izquierda, con yelmo lanza y escudo.

También nos dará información de tipo ornamental, con una gran cuadriga o biga, dependiendo de las monedas, situada en su cúspide y flanqueada por dos

${ }^{63}$ JACOBO, Álvaro, Op. Cit., pp. 90-93.

${ }^{64}$ Suet. Vesp. XXV: "Convenit inter omnis, tam certum eum de sua suorumque genitura semper fuisse, ut post assiduas in se coniurationes ausus sit adfirmare senatui, ut filios sibi successuros aut neminem.[...]».

${ }^{65}$ BMC II Vesp. 822.

${ }^{66}$ RIC 0360 Tit.

${ }^{67}$ BMC II Vesp. 721. 
esculturas de águilas y Júpiter presidiendo el frontón del templo, rodeado de grupos de luchadores. Sin embargo, no es la información iconográfica ni arquitectónica lo más representativo sino el mensaje propagandístico vinculado intrínsecamente a la imagen. Tal será el reconocimiento del mismo que las monedas que representan el templo en el reverso no tendrán leyenda explicativa de su contenido iconográfico, el mensaje era suficientemente claro tan sólo a través de la imagen ofrecida.

Con todo ello Vespasiano encarnaba la vuelta a la legalidad imperial, a la sanción divina de los gobernantes romanos, y, con ello, a la estabilidad del Estado, como bien representan las alegorías recogidas en la amonedación del periodo. Es el fin de un periodo de crisis, el inicio de una nueva edad de oro en la que los dioses, conformes con el nuevo gobernante, derramarían sus bienes sobre el pueblo de Roma, hasta hace poco oprimido por usurpadores tiránicos e impíos que habían llevado a la urbs al borde de su completa destrucción.

\section{CONCLUSIONES}

Tras los datos expuestos en el presente trabajo podemos afirmar que, efectivamente, Vespasiano se sirvió de un programa propagandístico coherente y perfectamente diseñado y estructurado como medio de afianzamiento de un poder en principio ilegítimo. La numismática, los omina y los datos aportados por las fuentes literarias transmiten a la población del imperio mensajes iconográficos e ideológicos destinados a la justificación de un poder en un principio precario.

La crisis ideológica del periodo inmediatamente anterior a la llegada al poder de Vespasiano, tras el desastroso gobierno de Nerón y las guerras civiles entre Galba, Otón y Vitelio, será el caldo de cultivo perfecto para el florecimiento de estos métodos de propaganda, que utilizando la receptividad exacerbada de la población, inmersa en plena crisis psicológica, lograrán afianzar en el poder a quien, en realidad, no se trata más que de un nuevo usurpador.

Dentro de dichos desastres tendrá especial relevancia la quema del templo de Júpiter Óptimo Máximo en el Capitolio romano durante la lucha entre vitelianos y flavianos, que llevará a la concepción de dicho hecho como la pérdida de apoyo por parte de los dioses a la ciudad eterna y, en última instancia, como el fin físico de la misma. De esta manera, los miedos «milenaristas» brotarían en una población atemorizada y crédula, siendo incluso percibidos y reflejados por parte de las fuentes del periodo.

Frente a la destrucción como fin del mundo romano nos encontramos, por tanto, con la reconstrucción del templo como renacer de la urbs, como el retorno a una edad de oro perdida bajo la égida de un emperador destacado por su pietas y protegido de los dioses. De este modo, el templo de Júpiter Óptimo Máximo ocupará un lugar privilegiado dentro de la propaganda flaviana, funcionando como principal punto de partida de la misma. Pero no solo el templo, sino también la divinidad 
será acogida como protectora directa de la familia imperial, como destaca la especial atención a las leyendas dedicadas a lovis Custos en las monedas del periodo.

Por tanto podemos afirmar, sin lugar a dudas, que la casa imperial creó y mantuvo a lo largo del reinado de todos los miembros de la dinastía Flavia un modelo propagandístico de gran calado en el cual la figura de Júpiter tuvo un papel capital. La dinastía Flavia se mantendría en el trono gracias a dicha operación propagandística, que justificaba el poder de una familia usurpadora en el apoyo de los dioses y en la entrega, por parte de los mismos, de la legalidad imperial de los Julio-Claudio.

\section{BIBLIOGRAFÍA}

ARATA, Francesco Paolo. «Observationi sulla topografía sacra dell'Arx Capitolina» MEFRA 122-1. (2010): 117-146.

BALL PLATNER, Samuel. A topographical dictionary of ancient Rome. «L'Erma» di Bretschneider. Roma. 1965.

BRAITHWAITE, Alfred William. C. Suetoni Tranquilli. Divus Vespasianus, Oxford, Clarendon Press. 1927.

CHARLESWORTH, Martin Percival. «The virtues of a Roman Emperor. Propaganda and the Creation of Belief» Proceedings of the British Academy, 23, (1937). pp. 105-133.

CRIADO, Cecilia. «Júpiter, emperador romano: La lectura política de la Tebaida de Estacio» Minerva. Revista de Filología Clásica. 14 (2000). pp. 87-106.

FEARS, Rufus. «Princeps a diis electus: The divine election of the emperor as a political concept at Rome». Papers and Monographs of the American Academy in Rome. Vol. XXVI. Rome. American Academy in Rome. 1977

— «The Cult of Jupiter and Roman Imperial Ideology» ANRW, 17.1. (1981): 3-141.

FERNÁNDEZ-ARDANAZ, Santiago y GONZÁLEZ FERNÁNDEZ, Rafael. «El fiscus iudaicus y las posiciones políticas de los cristianos de Roma bajo Domiciano» Gerión 23, núm. 1 (2005) 219-232

GRAF, Heinz Richard. Kaiser Vespasian. Untersuchungen zu Suetons VitaDivi Vespasiani, Stuttgart, Kohlhammer, 1937.

JACOBO, Álvaro. Auctoritas et maiestas: Historia, programa dinástico e iconografía en la moneda de Vespasiano Universidad de Alicante. 2003.

KRAUSS, Franklin Brunell. An Interpretation of the Omens, Portents, and Prodigies recorded by Livy, Tacitus, and Suetonius, Philadelphia, Pa. 1930.

LEVICK, Barbara. «Propaganda and Imperial Coinage», Antichthon, 16, (1982). pp. 104-116.

- Vespasian. Routledge, London. 1999.

LORSCH, Robin Stacey, Omina Imperii. The omens of power received by the Roman emperors from Augustus to Domitian. Their religious interpretation and political influence. Chapel Hill. University of North Carolina, 1993. 
MATTINGLY, Harold. Coins of the Roman Empire in the British Museum. vol. 2. Vespasian to Domitian Trustees of the British Museum, London. 1950-1966.

MATTINGLY, Harold, SYDENHAM, Edward Allen. The Roman imperial coinage. Vol. I, Augustus to Vitellius Spink. Londres. 1984

MONTERO, Santiago. Augusto y las aves. Las aves en la Roma del Principado: prodigio exhibición y consumo. Barcelona. Universitat de Barcelona. 2006. pp.167-168.

MOONEY, George W. C. .Suetoni Tranquilli de Vita Caesarum, libri VITWII. London, Longmans, 1930.

MORGAN, Gwyn. «Omens in Tacitus Histories I-III» (Ed. R. Lorsch and J. Isager) Divination and protents in the Roman World. Gylling. Odense University Press. 2000

REQUENA, Miguel. «El emperador predestinado: Los presagios de poder en época imperial romana». Cuadernos de la fundación Pastor, 2001, (2001), pp. 13-62.

RICHARDSON, Lawrence. A new topographical dictionary of Ancient Rome. The John Hopkins University Press. 1992.

STEINBY, Eva Margareta. (Ed.) LTUR. Tomo I-III. Roma. Quasar. 2000.

VIGOURT, Annie. Les Présages Imperiaux d'Auguste à Domitien. Paris. De Boccard. 2001.

WEST, Louis. C. «Imperial Publicity on Coins of the Roman Emperors» Classical Journal, 45, (1949) pp.19-26

WISEMAN, Timothy Peter. «Flavians on the Capitol» AJAH 3, 2, (1978) pp. 163-178.

ZECCHINI, Giuseppe. Los druidas. Madrid. Alderabán. 2002. 
